\title{
The resonance overvoltages in nonsinusoidal modes of extra high voltage transmission lines
}

\author{
V. V. Kuchanskyi, PhD, ORCID 0000-0002-8648-7942 \\ e-mailskilldur@ukr.net \\ Institute of Electrodynamics National Academy of Science of Ukraine, \\ Kyiv, Ukraine
}

\begin{abstract}
Due to the rising role of overhead lines extra high voltage there is a need of application of modern electronic devices that allow controlling modes of bulk electricity system. Durable resonance overvoltage may cause damage of electrical power equipment. This kind of overvoltage is caused by properties of the network and can be eliminated by changing the ratio between the parameters of the network and its mode. Unlike switching overvoltage that exist centiseconds, resonance overvoltage not only occur unexpectedly, but they may go on for a long time until the automatic action or action of personnel will not change electrical schemes or operation modes. The resonance overvoltage are neglected when selecting insulation or parameters for high-voltage surge arrester as this protective measure is calculated to limit switching overvoltage, not to extinguish a long resonance process. Therefore, the probability and development of system accidents due to resonance overvoltage is significant. One of the main causes of equipment failure in the main electrical network is overvoltage. Overvoltage are the values which according to the technical requirements exceed the maximum value of normal operating voltage. The reason is that the relatively small insulation reserve provides for the equipment of the electricity grid because of its high cost for a given voltage. Generally, cost of power systems insulation is a significant factor in capital investment. The main source of distortion in extra high voltage networks is nonlinearity of volt-ampere characteristic of magnetic shunt in unloaded power autotransformer. This mode causes the conditions for the significant overvoltage on even harmonics. It should be noted that the processes of the second harmonic overvoltage are generally known, but their specific occurrence conditions depend on many factors of abnormal mode. That is why the aim of the article is developing measure for reduction and prevention of overvoltage in accordance with conditions for their existence. In investigations residual magnetization is neglected because capacitance between autotransformer and circuit breaker is large enough. In the article the features of the operation of SF6 switches that should be considered when introducing them to the power lines of $750 \mathrm{kV}$. The switching control unit Switchsync F236 is one of such devices which enables to connect and disconnect contacts of poles circuit breakers at required time. This function of Switchsync F236 can be used not only for interruption of short circuit. One of the objectives of application Switchsync F236 is prevention of resonance overvoltage occurrence at closing extra high voltage line on no-load autotransformer. The analysis of electromagnetic switching transients when operating a three-phase auto recloser with really existing power transmission lines has been implemented. The influence of initial conditions of electromagnetic transients based on simulation has been analyzed. Based on the research it is proposed to use suppression equipment components with aperiodic current line switches. The research of recommended exposure settings of the controlled switching device on duration of current aperiodical component has been done. Recommendations on the use preinsertion resistors and switching units controlled have been proposed. The importance of application and prevention of resonance overvoltage caused research area which is presented in article.
\end{abstract}

Ref. 11, fig. 6.

Keywords — resonance overvoltage; control switching; simulation; nonsinusoidal mode.

\section{INTRODUCTION}

Trends of modern electricity grid point to the growing role of extra high voltage transmission lines as backbone and intersystem. It should be noted that the study for this lines must be done especially precisely, particularly with regard to the impact of sources of distortion. This is due to the lack of practical operational reserve insulation, designed for extreme values, as a reserve for extra high voltage (EHV) lines is expensive [1-5,8]. Thus, analysis of the possibility of overvoltages in power lines should be implemented not only in normal modes but also for abnormal (non-sinusoidal and unbalanced) modes.

At least in the main power networks air switches have been replaced by sulfur hexafluoride switches. This upgrade due to the fact that modern electrical industry does not produce air circuit breakers and in the case of damage it would be impossible to repair and restore electricity supply. Comparing to gas-insulated air circuit breakers they have certain advantages. The main of which are the speed, high breaking capacity and the possibility of application of controlled switching device. 


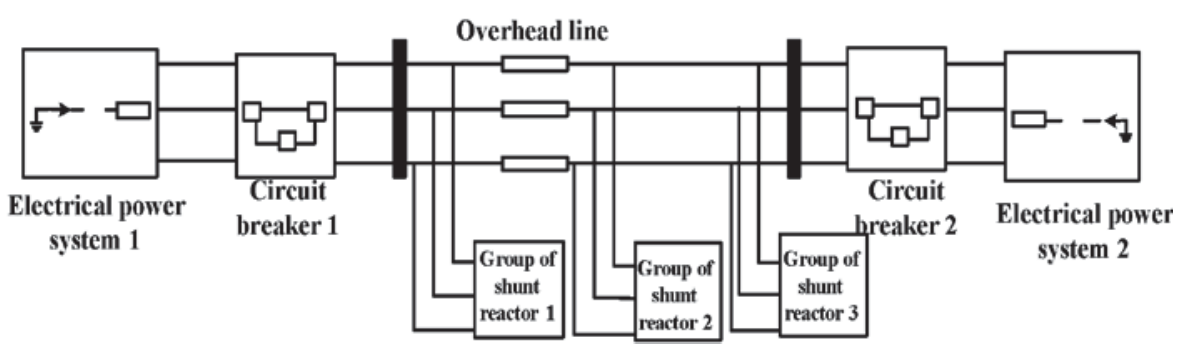

Fig. 1 The model of extra high voltage transmission line

\section{ANALYSIS OF PUBLISHED DATA AND PROBLEM DEFINITION}

Non-sinusoidal modes are characterized by the appearance of higher harmonics of current and voltage [4, $6,9-11]$. The distortions of voltage and current waveforms in the case of non-sinusoidal modes appear due to nonlinearity of the magnetization shunts of unloaded autotransformer. In recent years, much attention in studies is paid to electric-mode networks with fluctuations in the circles with steel elements with non-linear characteristic. This is the reason why occurrence of resonance overvoltages at frequencies that differ from the main is a complex phenomenon $[4,6,8]$.

The main direction of previous studies was focused on the development and application of mathematical models in order to obtain quantitative results for practical use $[10,11]$. They have not found the exact cause of overvoltages in the higher harmonic components, although cases of this type are known for a long time. From these results $[10,11]$ is unclear and unknown, themselves or switching modes lead to overvoltages at the higher harmonic. An investigation in area of overvoltages was performed with great simplification, because this type of overvoltages depends on many factors. Therefore, these studies are considered as comprehensive impossible.

It should be noted that the process of the second harmonic overvoltages are generally known, but the values of the characteristics depends on many factors of abnormal mode. It is therefore necessary to develop methods for identifying key factors which most of all influence on necessary and sufficient conditions for overvoltages during the design and operation of EHV lines.

\section{THE PURPOSE AND OBJECTIVES OF THE STUDY}

The aim of this paper is to develop the controlled switching device as a measure to prevent surges when the EHV line is connected to unloaded autotransformer. The controlled switch should reduce the value of overvoltages to level of effective traditional measures such as surge nonlinear varistors. This goal associates with resonant frequency of the line. According to certain ranges of frequency recommendations will be made for real EHV lines.

\section{THE SIMULATION MODEL FOR ANALYSIS OF RESO- NANCE OVERVOLTAGES IN NON-SINUSOIDAL MODE}

The model was developed to study the processes at single-phase auto-reclose in the environment MATLAB ${ }^{\circledR}$ / Simulink ${ }^{\circledR}[1,3]$ which are illustrated on Fig. 1. This model includes additional models of group shunt reactors and arc of alternating current to investigate resonance overvoltages as against [5-6]. The calculations to find the effective measure to prevent this kind of overvoltages were made. The three-phase power system is simulated by voltage sources with fixed voltage and inductances. The overhead line is simulated by two parts, which are given complex matrices with distributed elements or values on the forward and reverse sequence.

As noted above, the harmonic simulation over the second harmonic of every single factor cannot be considered independently. Changing one of the parameters may change the other, in other words, in this case there is a correlation between a particular network mode settings and parameters of the equipment.

Because of the reasons mentioned above, the simulation model has been developed in environment MATLAB $^{\circledR} /$ Simulink $^{\circledR}[1,9]$ Fig. 1 . The main feature of the application of this model is compulsory presence of three groups of shunt reactors (SHR). In practice is known [8] that harmonic overvoltages occur when length of line should compensate the charging capacity like in the case of installing three groups of SHR $[4,6,10]$.

There are some explanations of Fig.2: the value of normal operation voltage is $643 \mathrm{kV}$ and the $\mathrm{x}$-axis is time in seconds and y- axis is value of voltage. On Fig. 2 we can see value of voltages exceed normal operation voltage.

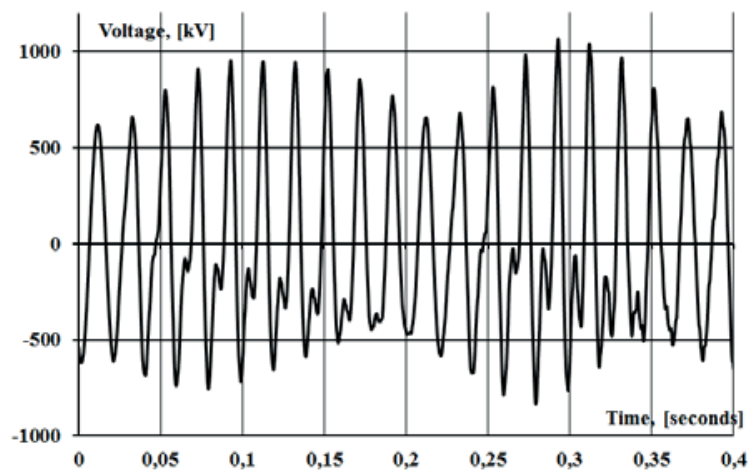

Fig. 2 Resonance overvoltages in abnormal mode 


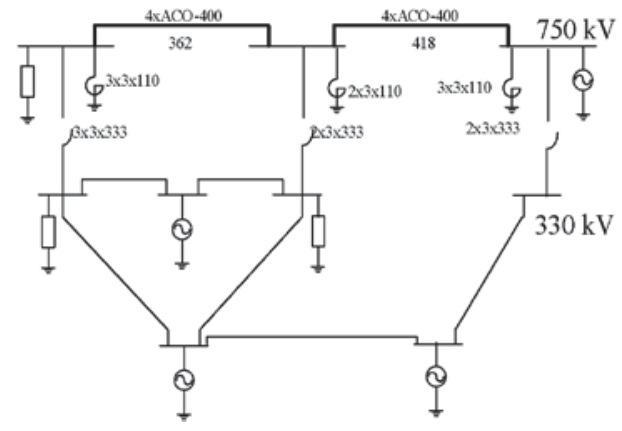

Fig. 3 Main power electrical grid

Due to the use of the simulation model (Fig. 1), the angles of ranges for which overvoltages values are reached: maximum values are $\delta \in[0 ; 140] \cup[200 ; 240]$; minimum values are $\delta \in[140 ; 215] \cup[275 ; 355]$. The overvoltages reach the maximum values in the zones of extremes of the sinusoidal voltage $(0 ; 140)$ and $(200 ; 240)$ $[4,5]$. The moments of switching the line to the unloaded autotransformer have been changed during the full period of the sinusoid, which allowed detecting a decisive factor in the appearance of the overvoltages.

\section{THE RESONANT FREQUENCY OF THE EHV TRANS- MISSION LINE}

For illustration the scheme of main power electric grid is shown on Fig. 3.

Resonant circuit is formed by connecting the phase of line to the unloaded autotransformer shown on Fig. 4. On Fig. 4 the following notations of equivalent circuit elements are made:

$L_{S}$ - equivalent inductance of the power system;

$L_{L}$ - inductance of the transmission line;

$L_{S H R}$-inductance of shunt reactor;

$C_{E}$ - capacity between phase of overhead line and earth;

$C_{M}$ - capacity between phases of overhead line;

$\omega_{-}$angular velocity.

The equation of resonant circuit current is:

$$
2 C_{M} \omega^{2} I\left[3\left(\mathrm{~L}_{S}+\mathrm{L}_{l} l\right)+L_{P} \mathrm{~L}_{l} l\right]-3=0 .
$$

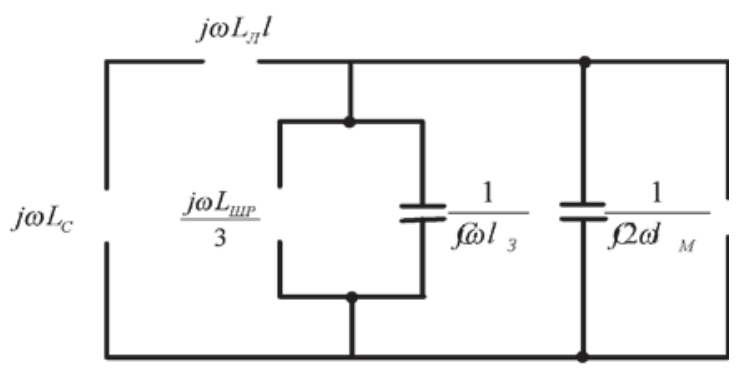

TABLE 1

\begin{tabular}{|c|c|c|c|c|c|}
\hline $\mathbf{L}_{0}, \mathbf{H}^{-4}$ & $\mathrm{C}_{0}, \mathbf{F}^{-9}$ & $\mathbf{L}_{1}, \mathbf{H}^{-3}$ & $C_{1}, F^{-8}$ & $\begin{array}{c}\begin{array}{c}\text { Number } \\
\text { of } \\
\text { groups }\end{array} \\
\text { SHR, n }\end{array}$ & $\begin{array}{c}\text { Length, } \\
(\mathrm{km})\end{array}$ \\
\hline 2.44 & 9.89 & 8.9 & 1.305 & 3 & 396 \\
\hline
\end{tabular}

The resonance overvoltages were obtained for real transmission line Vinnytska - Pivdennoukrainska power plant (Ukraine) with values of parameters which are shown in table 1.

From equation (1) the polynom of second degree was obtained, from which the resonance frequency is determined.

So we can find the resonance frequency of the line. Assess the reliability of this approach (1) is possible by comparing the values obtained from the simulation results on the simulation model. As seen from the table 2 an error is $3.2 \%$.

\section{CONTROLLED SWITCHING UNIT SWITCHSYNC F236}

The controlled commutation is used for eliminating the undesirable effects of transients during scheduled switching of capacitor banks, shunt reactors, overhead lines and power transformers. ABB's (Asea Brown Boveri Ltd.) high-voltage circuit breakers are well suited for controlled switching stable operating times.

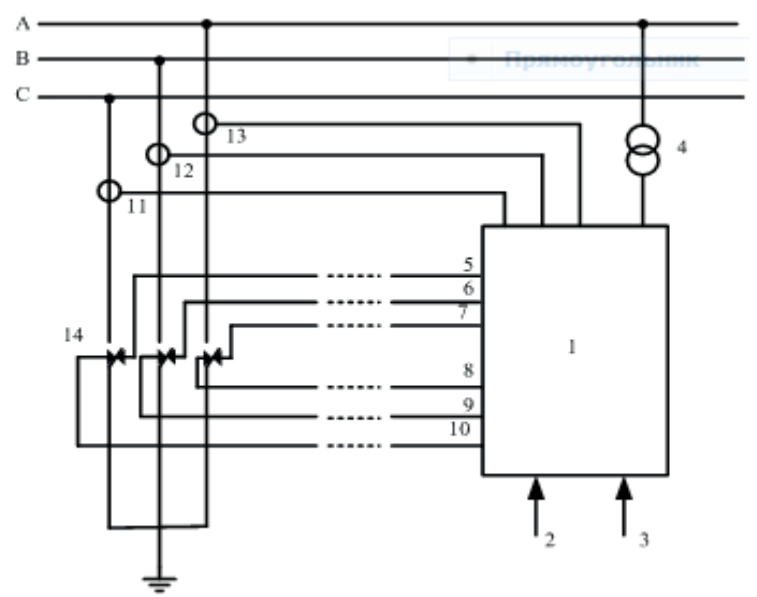

Fig. 5 The basic connection scheme of controlled switching unit Switchsync F236

TABLE 2

\begin{tabular}{|c|l|l|}
\hline Object of comparison & \multicolumn{1}{|c|}{$\begin{array}{c}\text { The resonant fre- } \\
\text { quency, } \mathbf{H z}\end{array}$} & $\boldsymbol{\delta}, \%$ \\
\hline A simulation model & 105 & 0 \\
\hline Polynom & 108.5 & 3.2 \\
\hline
\end{tabular}

Fig. 4 The resonance circuit of lineal part of overhead line 
TABLE 3

\begin{tabular}{|l|l|}
\hline Position & \multicolumn{1}{c|}{ Legend } \\
\hline 1 & Switchsync F236 \\
\hline 2 & Command entry \\
\hline 3 & Command entry \\
\hline 4 & Voltage transformer \\
\hline $5-10$ & Operating coil \\
\hline $11-13$ & Current transformer \\
\hline 14 & Circuit breaker \\
\hline
\end{tabular}

The simplest explanation of the unit operation is: Switchsync F236 receives a command to actuate circuit breaker of the control circuit and taking into account the expected operating times its own switch transmit them to the circuit breaker at the moment at which provides closing or opening contacts on desired voltage phase. The basic connection scheme of controlled switching unit Switchsync F236 is shown on Fig. 5.

In the table 3 imposed positions and legends of the basic connection scheme of controlled switching unit Switchsync F236 are shown.

ABB's high-voltage circuit breakers are well suited for controlled switching featuring stable operating times as well as steep and stable dynamic dielectric withstand capability. To synchronize the time of the contacts opening special devices are developed and used, for example, Switchsync F 236 ABB.

On Fig. 6 we can see that controlled commutation reduces overvoltages. The marking of axis are the same as on Fig. 2.

The resonance scheme has been composed for investigation factors that really influence on occurrence of harmonic overvoltage. It is shown that there are overhead lines with natural frequency nearly $100 \mathrm{~Hz}$. The condition of resonance current can be used to express estimation of overvoltages in non-sinusoidal modes.

The factor which is critical for occurrence of non-sinusoidal overvoltage has been defined while modelling. In accordance with it results have been obtained and a new measure for prevention and reduction overvoltages on higher harmonic components was proposed. The measure is based on the use of controlled switching device whereby contact closure switch was provided at the right time at which the value of overvoltages does not threaten isolation of equipment.

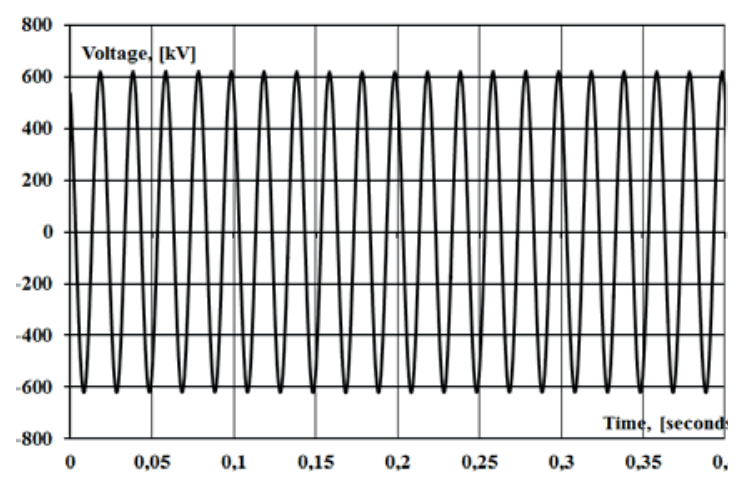

\section{REFERENCES}

[1] V. Kuznetsov, Y. Tugay and V. Kuchanskyy, «Doslidzhennia vplyvu transpozitsii linii elektroperedachi nadvisokoi naprugi na anormalni perenapruhi [Investigation of transposition EHV transmission lines on abnormal overvoltages],» Technical electrodynamics, no. 6, p. 51-56, 2013. URL: http://techned.org.ua/2013 6/st11.pdf

[2] I. Naumkin, M. Balabin, N. Lavrushenko and R. Naumkin, "Simulation of the $500 \mathrm{kV} \mathrm{SF} 6$ circuit breaker cutoff process during the unsuccessful three-phase autoreclosing," in International Conference on power systems Transients, Delft, The Netherlands, 2011.

URL:

http://www.ipstconf.org/papers/Proc_IPST2011/11IPST025.p df

[3] V. Kuchanskyy, «Kriterli vynyknennia rezonansnykh perenapruh $\mathrm{v}$ anormalnykh rezhymakh IInIi elektroperedach nadvysokoi napruhi [Criteria of resonance overvoltages occurrence in abnormal conditions of extra high voltage transmission lines],» Scientific works of Vinnitsa National Technical University, no. 4, p. 51-54, 2016. URL: https://visnyk.vntu.edu.ua/index.php/visnyk/article/view/1948/ $\underline{1949}$

[4] M. E. Zevallos and M. C. Tavares, "Single-Phase AutoRecloser Studies: Influence of Transversal Parameters of a Transmission System on the Secondary Arc Current Reduction during SPAR," in International Conference on power systems Transients, Delft, The Netherlands, 2011. URL: http://www.ipstconf.org/papers/Proc_IPST2011/11IPST011.p df

[5] V. Kulik та S. Wisniewski, «KombInovanI modelI normalnih rezhimIv elektrichnih sistem $\mathrm{z}$ urahuvannyam osoblivostey dovgih IInIy elektroperedachI [Combined electric model normal mode systems with regard to extra-long power lines],» Scientific works of Vinnitsa National Technical University, no. 1, pp. 1-7, 2012.

[6] A. Ravluk and V. Stetsyk, "Modeling of switching processes of high voltage lines $750 \mathrm{kV}$," Journal of Lviv Polytechnic National University. Electrical power engineering and electromechanical systems, no. 840, pp. 102-107, 2016.

[7] Y. Tugay, "The resonance overvoltages in EHV network," in 10th International Conference on Electrical Power Quality and Utilisation, Lodz, Poland, 2009.

DOI: $10.1109 /$ EPQU.2009.5318812

[8] S. R. Atmuri, R. S. Thallam, D. W. Gerlach, T. G. Lundquist and D. A. Selin, "Neutral reactors on shunt compensated EHV lines," in International Conference of Transmission and Distribution, Chicago IL, USA, 1994.

DOI: $10.1109 /$ TDC .1994 .328443

[9] M. Nagpal, T. G. Martinich, A. Bimbhra and D. Sydor, "Damaging Open-Phase Overvoltage Disturbance on a ShuntCompensated 500-kV Line Initiated by Unintended Trip," IEEE Transactions on Power Delivery, vol. 30, no. 1, pp. 412419, February 2015. DOI: 10.1109/TPWRD.2014.2360144

[10] I. Naumkin, «Crash when switching of gas insulated circuit breakers $500-1150 \mathrm{kV}$ overhead line compensated,» Electricity, № 10, pp. 22-32, 2012.

[11] I. Sadeghkhani, A. Ketabi and R. Feuillet, "New Approach to Harmonic Overvoltages Reduction during Transformer Energization via Controlled Switching," in 15th International Conference on Intelligent System Applications to Power Systems, Curitiba, Brazil, 2009.

DOI: $10.1109 /$ ISAP.2009.5352837

Надійшла до редакції 23 червня 2017 р.

Fig. 6 Reducing of resonance overvoltages by SwitchSync F236 


\section{Резонансні перенапруги у несинусоїдальних режимах ліній електропередач надвисокої напруги}

Кучанський В. В., к.т.н., ORCID 0000-0002-8648-7942

e-mailskilldur@ukr.net

Інститут електродинаміки НАН України, Київ, Україна

Реферат-Резонансні перенапруги можуть спричинити пошкодження електричного силового обладнання. Поява такого роду перенапруг зумовлена властивостями мережі і може бути усунена шляхом зміни співвідношення між параметрами мережі та їі режимом. На відміну від комутаційних перенапруг, які існують протягом декількох періодів промислової частоти, резонансні перенапруги виникають не тільки несподівано, але вони можуть тривати протягом тривалого часу, до поки спрацювання пристроїв релейного захисту або дії персоналу не змінять електричну схему або режим. Резонансні перенапруги не враховують при виборі ізоляції або параметрів обладнання, бо сучасні захисні заходи розраховані для обмеження комутаційних перенапруг, а не для подавлення тривалих резонансних процесів. Таким чином, ймовірність і розвиток системних аварій через резонансні перенапруги с значною. Важливість розробки заходів попередження резонансних перенапруг зумовило напрямок досліджень, які представлені в статті.

Бібл. 11, рис. 6.

Ключові слова - резонансні перенапруги; керована комутація; імітаційна модель; несинусоӥдальні режими.

\section{Резонансные перенапряжения}

\section{в несинусоидальных режимах линий электропередачи сверхвысокого напряжения}

Кучанский В. В., к.т.н., ORCID 0000-0002-8648-7942

e-mailskilldur@ukr.net

Институт электродинамики НАН Украины,

Киев, Украина

Реферат-Резонансные перенапряжения могут привести к повреждению электрического силового оборудования. Появление такого рода перенапряжений обусловлено свойствами сети и может быть устранено путем изменения соотношения между параметрами сети и ее режимом. В отличие от коммутационных перенапряжений, которые сушествуют на протяжении нескольких периодов промышленной частоты, резонансные перенапряжения возникают не только неожиданно, но они могут продолжаться в течение длительного времени, до тех пор, пока срабатывание устройств релейной защиты и действия персонала не изменят электрическую схему или режим. Резонансные перенапряжения не учитывают при выборе изоляции или параметров оборудования. Современные защитные мероприятия рассчитаны для ограничения коммутационных перенапряжений, а не для подавления длительных резонансных процессов. Таким образом, вероятность развития системных аварий из-за резонансных перенапряжений является значительной. Важность разработки мер предупреждения резонансных перенапряжений обусловило направление исследований, которые представлены в статье.

Библ. 11, рис. 6.

Ключевые слова - резонансные перенапряжения; управляемая коммутация; имитационная модель; несинусоидальные режимы. 